\title{
Evaluation of Soil Characteristics and Environmental Parameters of Arid-Semi Arid (Desert) Truffles from Eastern Turkey
}

\author{
Türkiye'nin Doğusunda Kurak-Yarı Kurak (Çöl) Trüflerin Toprak \\ Özellikleri ve Çevresel Parametrelerinin Değerlendirmesi
}

\author{
Research Article
}

Mehmet Akyüzi,*, Sevda Kirbağํ, Yasemin Gürhan1, Burak Bircan²

'Department of Biology, Faculty of Science and Arts, Bitlis Eren University, Bitlis, Turkey.

${ }^{2}$ Department of Biology, Faculty of Science, Fırat University, Elazığ, Turkey.

\section{A B S TR AC T}

T he ecological characteristics of arid-semi arid truffles from Eastern Turkey were investigated. The habitat and climate characters of the collection sites were determined and soil samples from localities were analysed. The light strength, temperature, humidity, air flow and air velocity at the areas were recorded to be $17.7 \mathrm{klux}$ to $303.9 \mathrm{klux}, 7.8^{\circ} \mathrm{C}$ to $24.3^{\circ} \mathrm{C}, 11.9 \%$ to $43.2 \%, 3702.6 \mathrm{ft}^{3} / \mathrm{min}$ to $8941.6 \mathrm{ft}^{3} / \mathrm{min}$, and $3.6 \mathrm{~km} / \mathrm{h}$ to $16.9 \mathrm{~km} / \mathrm{h}$, respectively. Environmental parameters match the climatic requirements, which is normal for the region when spring is concerned. The soil samples contained $42.59 \%$ to $91.46 \%$ sand, $4.49 \%$ to $38.43 \%$ clay, $4.04 \%$ to $25.91 \%$ silt, $8.54 \%$ to $57.41 \%$ silt-clay. The soil types included sandy, sandy-loam, clay-loam, loam-sand, sandyclay-loam types. The soil examples were understood to have alkaline characteristics and had a lime content. The level of organic material and nitrogen was low, whereas the amounts of phosphorus, potassium and sodium were high. Based on our studies and observations, it is possible to claim that habitat, host plant, climate, and soil types are as important as precipitation for the healthy growth of truffles.

\section{Key Words}

Arid-semi arid truffle, climatic parameters, Picoa, soil characteristics, Terfezia.

\section{öz}

\begin{abstract}
Türkiye'nin doğusunda kurak-yarı kurak trüflerin ekolojik özellikleri incelenmiştir. Toplama alanlarının habitatı ve iklim özellikleri belirlenmiş ve elde edilen toprak örnekleri analiz edilmiştir. Çalışılan alanların ışık şiddeti, sıcaklık, nem, hava debisi ve hava hızı sırasıyla 17.7-303.9 klux, 7.8-24.3º $\mathrm{C} \% 11.9-43.2,3702.6-8941.6 \mathrm{ft}^{3} / \mathrm{min} \mathrm{ve}^{2}$ 3.6-16.9 km/h olarak kaydedilmiştir. Ölçülen çevresel parametreler iklimsel ihtiyaçlarla örtüşmektedir. Ölçümler bölgenin bahar ayı koşulları itibariyle normal düzeydedir. Toprak örnekleri \%42.59-91.46 kum, \%4.49-38.43 kil, \%4.04-25.91 toz, \%8.54-57.41 toz-kil ve toprak tipleri ise kumlu, kumlu-balçık, killi-balçık, balçıklı-kum ve kumlu-killi-balçıklı toprak türünü içermektedir. Toprak örneklerinin alkali yapıya sahip olduğu ve kireç içerdiği anlaşılmıştır. Organik madde ve azot oranının düşük olduğu fakat fosfor, potasyum ve sodyum içeriğinin yüksek olduğu görülmüştür. İnceleme ve gözlemlerimize dayanarak kurak, yarı kurak ya da çöl trüflerin sağlıklı yetişmesi için yağış kadar habitat, mikorizal bitki, iklim ve toprak tiplerinin de önemli olduğu söylenebilir.
\end{abstract}

\section{Anahtar Kelimeler}

Kurak-yarı kurak trüfler, iklimsel parametreler, Picoa, toprak özellikleri, Terfezia.

Article History: Received: Apr 22, 2017; Revised: Jun 25, 2017; Accepted: Oct 27, 2017; Available Online: Dec 25, 2017. DOI: $10.15671 / \mathrm{HJBC} .2018 .180$

Correspondence to: M. Akyüz, Department of Biology, Faculty of Science and Arts, Bitlis Eren University, Bitlis, Turkey. 


\section{INTRODUCTION}

lobal warming has been destroying the ha3 bitat of living creatures, their area of distribution and the species. The excessive gathering of the species and their commercial use cause extinction. Overgathering is an important threat in Turkey. The decrease in the number of species has caused scientists to adopt new approaches to the subject today, and scientific research focusing on ecosystems, aiming at understanding their importance, have gained speed [1].

Earth is divided into different eco-geographic regions based on their climatic characteristics, and their plant and animal diversity. Anatolia is one of the unique places on earth in terms of its geological history and ecological characteristics, and it is a center for many species to take shelter and protect their genes. It also has a priviliged position in terms of its rich biodiversity because of it geographical location where three continents meet [2-4].

Truffles are edible hypogeous fruit bodies that go under the genera of fungi belonging to the class Ascomycetes G.Winter. Terfezia (Tul. \& C.Tul) Tul. \& C.Tul. (Pezizaceae Dumort.), Tirmania Chatin (Pezizaceae Dumort.), Picoa Vittad. (Pyronemataceae Corda), and Tuber P.Micheli ex. F.H Wigg (Tuberaceae Dumort.) are classified in different taxa in Pezizales J.Schrot [5]. These can be observed in most of the arid and semiarid zones of the Middle East and the Mediterranean Basin world. Desert truffle species including Terfezia, Tirmania and Picoa form mycorrhizae mainly on the roots of the plants belonging to the Cistaceae family, which include different species of the genus Helianthemum (L.) Miller [6-10].

Truffle types can grow in various areas depending on the habitat's climate, altitude, vegetation and the soil structure. Unfortunately, there is little data on the effects of climate change on truffle fruiting. In a similar way, the effects of environmental conditions on truffle growth in Turkey is also not well investigated [11], mainly because truffle fungi have received less attention than epigeous fungi, and other plants and animals [12].

This study presents investigations on bioecology of arid-semi arid truffles collected from the
Elazığ-Malatya region of Turkey. The study focuses on the habitat description, and the climatic and soil characteristics of truffles, which are a mushroom type with high nutritious and economic value, analysed together with the characteristics of their distributional habitats.

\section{MATERIALS and METHODS}

\section{Study Areas and Obtaining the Arid-Semi Arid (Desert) Truffles}

According to Akyüz et al. [13] wild samples of fresh Terfezia and Picoa species were collected from the Malatya-Elazığ provincial border zone and its vicinity that cuts through the area around N $38^{\circ} 19^{\prime}-43^{\prime} \mathrm{E} 038^{\circ} 19^{\prime}-51^{\prime}$ with an altitude of 690-1375 m.

\section{Sampling and the Methods for Soil Analysis}

Soil samples were taken from a depth of about 10$15 \mathrm{~cm}$ from the surface by means of a stainless steel crab during the fieldwork. These were airdried in the laboratory under a heat of $25^{\circ} \mathrm{C}$. The dried samples were first crushed with a wooden pestle, then screened through a $2 \mathrm{~mm}$ sieve, and finally analysed to determine some of the physical and chemical characteristics. The physico-chemical properties of the samples were determined with teh methods described below.

The distribution of soil texture types including sand, clay, and silt were analysed using the hydrometer method [14]. The $\mathrm{CaCO}_{3}$ content was determined by the Scheibler calcimeter method [15]. For the amount of organic matter the methods modified by Walkley-Black $[16,17]$ was used, and the total nitrogen amount was determined using the Kjeldahl digestion and distillation procedure [18]. The $\mathrm{pH}$ and electrical conductivity (mmhos/cm) were measured in water with a 1:2.5 ratio of soil solution $[15,19]$. The amount of phosphorus was calculated by the vanadomolybdate method of Murphy \& Riley [20], and $\mathrm{Na}$ and $\mathrm{K}$ amounts were determined by using an atomic absorption spectroscopy device (AAS).

\section{The Measurement of the Environmental Parameters}

The illuminance level (klux), humidity (\%), heat changing $\left({ }^{\circ} \mathrm{C}\right)$, air velocity $(\mathrm{km} / \mathrm{h})$ and air flow (CFM, $\left.\mathrm{ft}^{3} / \mathrm{min}\right)$ of the area the truffle growth were 
measured using a Geofennel FLM 400 Data lux meter, FHT 70 Datalog temperature and humidity calculator, and FTA 1 thermometer-anemometer, respectively.

\section{RESULTS}

\section{Habitat and Other Characteristics}

It was detected that arid and semi-arid truffle types grow in the study area from the beginning of March to the end of May, and rarely continue until mid-July (Figure 1a). In areas with sandy soil with low permeability, which dries quickly (Figures $1 b-c, f$ ), it is easier to locate truffles when the temperature is around $\sim 10-23^{\circ} \mathrm{C}$. The soil bulges and cracks in these areas (Figure 1g-h), sometimes close to the soil surface. These fungi are taken out of soil by the locals, who use a tool with a pointed tip, as they know where these grow. At times when the soil surface does not crack, collection of truffles is conducted by "domalan and kumi" collectors (Figure 1ı), who hit the soil with sticks at areas around where $H$. salicifolium and rarely $H$. ledifolium mostly grow (Figures $1 d-$ e), and who detect their location based on the differences in sound. On the other hand, truffles can be collected by using a digging tool in areas where the soil buldges and cracks after it becomes warmer following spring rains.

Truffle types can grow in this area abundantly based on the favourable climatic conditions. The area where this mushroom grows are barren lands with a sandy soil, where no woody plants, but
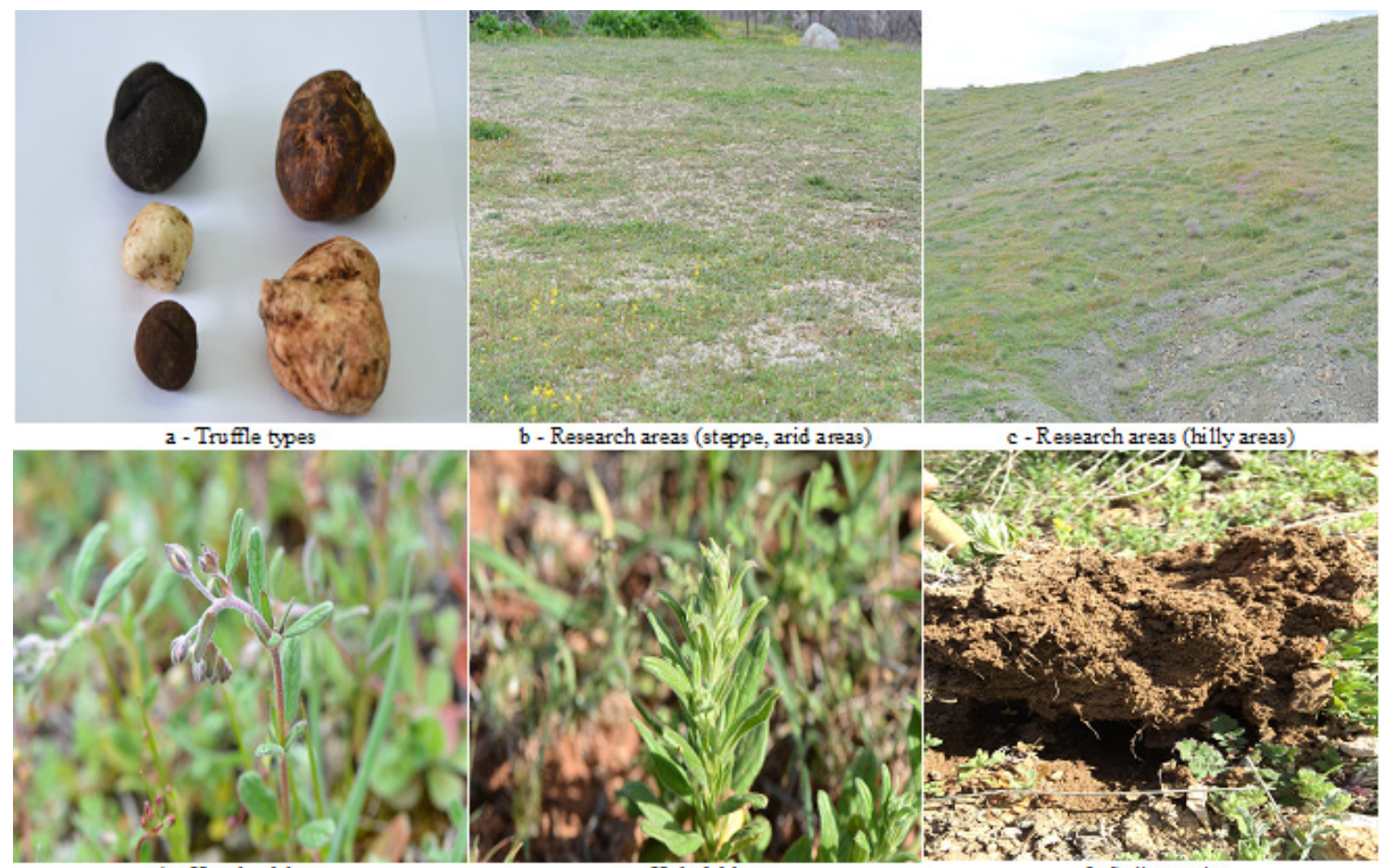

b - Research areas (steppe, arid areas)

c - Research areas (hilly areas)

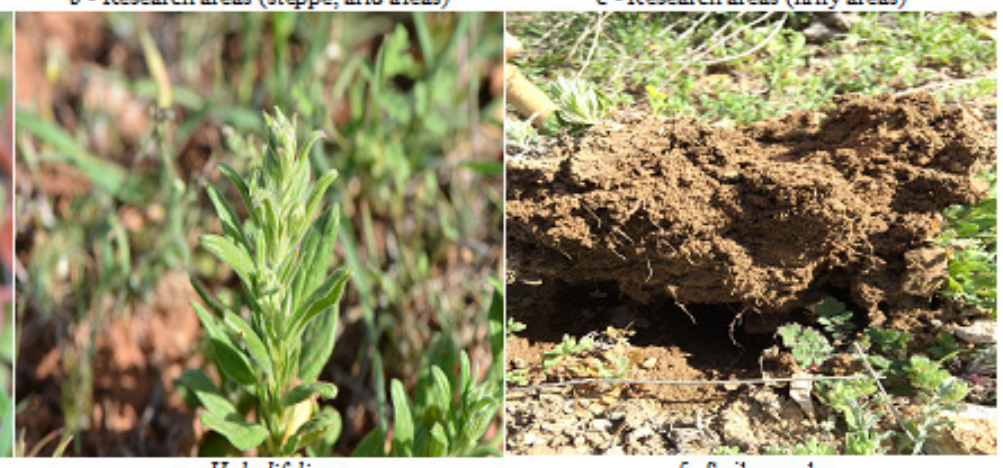

d- $H$. salicifolium

e - $H$. ledifolium

f - Soil sample

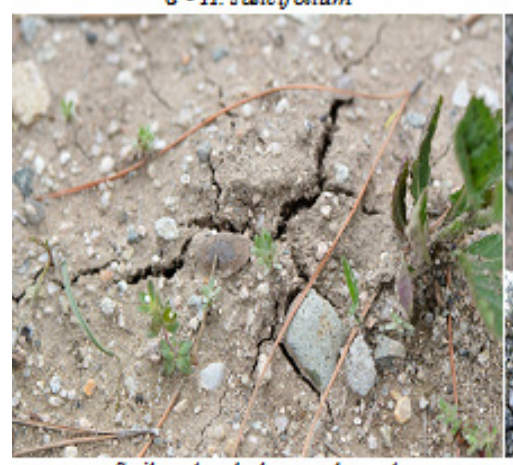

g- Soil makes bulges and crack

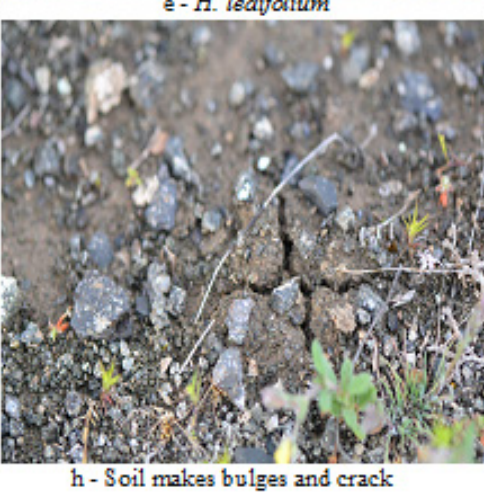

Figure 1. The truffle types, host plants, and soil samples etc. that were collected from the Elazığ-Malatya areas. 
annual herbaceous plants grow. All truffle samples are generally known as "kumi" or "domalan" in the research area. The local names for $T$. boudieri include "domalan, kumi", "kuş-karga mantarı, maf, makelik, maklik" for P. lefebvrei, "beyaz kumi, domalan" for T. olbiensis, and "siyah - kara kumi" for P. juniperi.

It was observed that T. boudieri is the only product that has an economic value as it brings profit. $P$. lefebvrei, T. olbiensis and P. juniperi, which are used for daily consumption and are more popular amongs to the locals, do not have economic value, as the first one is too small, the second one degrades quickly, and the third one can be rarely found. It was determined that $T$. olbiensis is more attractive when compared to other types, because of its aroma and smell. It was also observed that $T$. claveryi can rarely be found in the area and can be confused with $T$. boudieri by the local people [21]. The most common and well known types include T. boudieri, $P$. lefebvrei and T. olbiensis, whereas T. claveryi and $P$. juniperi, which are now well-known and are rarely found in small areas.

\section{The Environmental Parameters of the Truffle Habitat}

The environmental parameters from the studied area, where the Terfezia and Picoa species grow naturally, in the Elazığ-Malatya Province, included the light strength, heat, humidity, air flow, and air velocity. The observed values varied between $17.7 \mathrm{klux}$ and $303.9 \mathrm{klux}, 7.8^{\circ} \mathrm{C}$ and $24.3^{\circ} \mathrm{C}, 11.9 \%$ and $43.2 \%$, the $3702.6 \mathrm{ft} 3 / \mathrm{min}$ and $8941.6 \mathrm{ft} 3 /$ $\min$, and $3.6 \mathrm{~km} / \mathrm{h}$ and $16.9 \mathrm{~km} / \mathrm{h}$ respectively (Table 1). These values were understood to be different or sometimes similar based on the altitude, geographical location, the time period of measurement and the season (Table 1).

\section{The Soil Characteristics of the Truffle Growth Area}

The physical and chemical characteristics of the soil samples from the locations, where different truffle types grow ( $T$. boudieri, $T$. claveryi, $T$. olbiensis, $P$. lefebvrei ve $P$. juniperi) are shown in Table 2. The characteristics of the soil samples collected from where the truffles grow were analysed and the amounts of sand, clay, silt, siltclay, sandy clay, sandy-loam, clay-loam, loam- sand, and sandy-clay-loam in the soil, the $\mathrm{pH}$ level, total amount of lime, active lime, salt, organic material, nitrogen, and of various elements were recorded. The recorded amounts, that can be seen in Table 2, indicate that the soil characteristics can vary based on the geographical location, the area where the species were collected from, the altitude, and biotic and abiotic factors (Table 2).

\section{DISCUSSION}

It has been indicated earlier that the mycorrhizal structures between the truffle and the host plant can be affected by biotic and abiotic causes that include rainy seasons, amount of precipitation, dryness, climatic conditions, humidity, salination, types of the soil $[6-8,10,22-28]$. The widespread growth of wild truffle species in different regions are thought to be due to the apropriate ecology, habitat, soil types, host plant, and environmental and climatic conditions as stated by previously mentioned reports.

Most of the Asian-Mediterranean regions, where desert truffle populations can grow, reflect similar climatic attributes: these are inland steppe areas which are characterized by semiarid to arid continental conditions with dry summers and wet winters. The annual precipitation has been recorded to be in between 300 and $600 \mathrm{~mm}$ in the relatively wet semiarid areas, and between 50 and $250 \mathrm{~mm}$ in the arid areas. Rainfall is often erratic and droughts are common [29]. Truffles mostly prefer areas which have cool winters, damp and warm springs, and hot summers. Other climatic factors that affect truffle production, include day length, amount of sunshine, level of humidity, vapor pressure deficits and evaporation [11]. It was determined that the environmental parameters can be similar or can change based on the geographical location, the area where the species were collected from, the altitude, the time period of measurement and the season [see Table 1,6-8, 10-11, 30-33]. Our research has shown that in our study area, where Terfezia and Picoa species grow naturally, the light strength, the heat, humidity, air flow and the air velocity match the climatic requirements mentioned above, which is normal for the region when spring is concerned (see Table 1). 
Table 1. Environmental parameters of arid-semi arid (desert) truffles from Eastern Turkey.

\begin{tabular}{|c|c|c|c|c|c|c|}
\hline \multirow{2}{*}{$\begin{array}{c}\text { Truffle } \\
\text { types }\end{array}$} & \multirow[t]{2}{*}{ Locality } & \multicolumn{5}{|c|}{ Environmental parameters } \\
\hline & & $\begin{array}{l}\text { Illuminance } \\
\text { (klüx) }\end{array}$ & $\begin{array}{c}\text { Temperature } \\
\left({ }^{\circ} \mathrm{C}\right)\end{array}$ & $\begin{array}{l}\text { Humidity } \\
(\%)\end{array}$ & $\begin{array}{l}\text { Air velocity } \\
\left(\mathrm{CFM}, \mathrm{ft}^{3} / \mathrm{min}\right)\end{array}$ & $\begin{array}{l}\text { Air flow } \\
(\mathrm{km} / \mathrm{h})\end{array}$ \\
\hline 1,4 & Kale - Malatya & $59.6 \pm 9.9^{\text {hii }}$ & $16.8 \pm 0.8$ defghiij & $24.1 \pm 1.0$ efghii & $5323.2 \pm 503.2 \mathrm{abcd}$ & $8.7 \pm 0.8$ fghii \\
\hline $1,3,4$ & Kıyıcak, Kale - Malatya & $28.5 \pm 3.5^{\mathrm{bcd}}$ & $16.9 \pm 0.1^{\text {defghiij }}$ & $19.9 \pm 1.1$ def & $4224.8 \pm 411.9 \mathrm{ab}$ & $6.9 \pm 0.6$ abcdefght \\
\hline 1,4 & Kapıkaya, Centre - Malatya & $25.5 \pm 0.9 \mathrm{bc}$ & $7.8 \pm 0.1^{\mathrm{a}}$ & $43.2 \pm 0.9^{n}$ & $5384.0 \pm 286.9$ abcd & $8.7 \pm 0.6$ efghii \\
\hline 1,4 & Çolaklı, Centre - Malatya & $26.9 \pm 0.9 \mathrm{bc}$ & $7.8 \pm 0.4^{\mathrm{a}}$ & $42.5 \pm 0.4^{n}$ & $4427.8 \pm 273.5$ abc & $7.2 \pm 0.5^{\text {bcdefghii }}$ \\
\hline 1,4 & Yeniköy, Centre - Malatya & $26.2 \pm 1.6^{\mathrm{bc}}$ & $12.9 \pm 0.8^{\mathrm{bc}}$ & $40.2 \pm 2.1 \mathrm{mn}$ & $8620.0 \pm 1355.5 \mathrm{ghl}$ & $5.3 \pm 1.3$ abcdefg \\
\hline $1,3,4,5$ & Meydancık, Battalgazi - Malatya & $24.8 \pm 0.9 \mathrm{abc}$ & $11.1 \pm 0.6^{b}$ & $41.9 \pm 1.9^{n}$ & $4799.2 \pm 699.1$ abcd & $7.8 \pm 1.2^{\text {cdefghii }}$ \\
\hline $1,3,4$ & Yarımcahan, Battalgazi - Malatya & $29.1 \pm 1.4$ bcde & $11.8 \pm 0.2^{b}$ & $40.0 \pm 1.0 \mathrm{mn}$ & $5169.6 \pm 532.2^{\mathrm{abcd}}$ & $8.5 \pm 0.9$ efghii \\
\hline $1,3,4$ & Çolakoğlu, Battalgazi - Malatya & $41.3 \pm 1.3$ efg & $13.1 \pm 0.2^{b c}$ & $25.6 \pm 0.6 \mathrm{~lm}$ & $3953.0 \pm 829.8$ ab & $5.9 \pm 0.6$ abcdefg \\
\hline $1,3,4$ & Adagören, Battalgazi - Malatya & $40.5 \pm 0.7$ def & $14.5 \pm 0.8^{\mathrm{cd}}$ & $34.5 \pm 1.1 \mathrm{kl}$ & $4580.8 \pm 888.9 \mathrm{abcd}$ & $7.5 \pm 1.5^{\text {bcdefghii }}$ \\
\hline $1,3,4$ & Ağılyazı, Battalgazi - Malatya & $122.9 \pm 9.0^{\circ}$ & $17.4 \pm 0.8^{\text {fghili }}$ & $28.3 \pm 2.6^{i j}$ & $4566.8 \pm 418.6$ abcd & $7.5 \pm 0.7$ bcdefghii \\
\hline $1,3,4$ & Kuluşağı, Battalgazi - Malatya & $58.3 \pm 1.6^{\mathrm{hl}}$ & $16.6 \pm 1.4^{\text {defghı }}$ & $22.5 \pm 3.9$ defghı & $4511.4 \pm 317.5^{\text {abcd }}$ & $7.4 \pm 0.5^{\text {bcdefghii }}$ \\
\hline $1,3,4$ & Şişman, Battalgazi - Malatya & $48.4 \pm 1.9$ fgh & $17.3 \pm 1.3$ efghiij & $26.6 \pm 1.8^{\text {hiij }}$ & $6657.6 \pm 332.6^{\text {defgh }}$ & $3.6 \pm 0.2^{\mathrm{a}}$ \\
\hline 1,4 & Gümüşlü, Arguvan - Malatya & $53.4 \pm 1.9 \mathrm{gh}$ & $15.8 \pm 0.3^{\text {defgh }}$ & $21.8 \pm 0.5^{\text {defgh }}$ & $5254.0 \pm 645.1^{\mathrm{abcd}}$ & $7.8 \pm 1.8$ cdefghii \\
\hline 1,4 & Morhamam, Arguvan - Malatya & $48.9 \pm 1.3^{\mathrm{fgh}}$ & $16.7 \pm 0.6$ defghii & $24.9 \pm 1.0$ fghiij & $8412.0 \pm 1694.1^{\mathrm{ghl}}$ & $5.2 \pm 0.9$ abcdef \\
\hline 1,4 & Karababa, Arguvan - Malatya & $68.6 \pm 1.9 \mathrm{ij}$ & $14.7 \pm 0.2$ cde & $\underset{\text { defghı }}{22.5 \pm 0.8}$ & $\begin{array}{c}5653.8 \pm 585.6 \\
\text { abcde }\end{array}$ & $7.9 \pm 2.8$ cdefghii \\
\hline 1,4 & Topaluşağı, Baskil -Elazığ & $19.6 \pm 1.1$ ab & $16.9 \pm 0.1$ defghii & $42.1 \pm 0.6^{n}$ & $3702.6 \pm 554.7^{\mathrm{a}}$ & $16.9 \pm 2.7^{k}$ \\
\hline 1,4 & Habipuşağı, Baskil - Elazığ & $18.5 \pm 0.5 \mathrm{ab}$ & $17.7 \pm 0.2^{\text {fghlijk }}$ & $39.9 \pm 0.7 \mathrm{lmn}$ & $5422.8 \pm 895.9 \mathrm{abcd}$ & $8.3 \pm 1.2$ defghii \\
\hline 1,4 & Kuşsarayı, Baskil - Elazığ & $17.7 \pm 0.7$ ab & $17.8 \pm 1.7$ ghilik & $35.7 \pm 0.8^{\mathrm{Im}}$ & $8082.6 \pm 695.1^{\mathrm{fghl}}$ & $13.5 \pm 1.1^{1 \mathrm{k}}$ \\
\hline $1,3,4,5$ & Alangören, Baskil - Elazığ & $70.9 \pm 4.8^{i j}$ & $17.2 \pm 0.7$ efghiij & $19.4 \pm 1.2$ de & $8278.8 \pm 401.3^{\mathrm{fghl}}$ & $4.4 \pm 0.2 \mathrm{abc}$ \\
\hline $1,3,4,5$ & Deliktaş, Baskil - Elazığ & $35.1 \pm 1.7$ cde & $15.3 \pm 0.4^{\text {cdefg }}$ & $17.3 \pm 0.4^{\mathrm{bcd}}$ & $4394.4 \pm 219.7$ abc & $7.5 \pm 0.9$ bcdefghii \\
\hline $\begin{array}{c}1,2,3 \\
4,5\end{array}$ & Gemici, Baskil - Elazığ & $91.4 \pm 2.9 \mathrm{kl}$ & $16.5 \pm 0.2^{\text {defghı }}$ & $13.9 \pm 1.3 \mathrm{abc}$ & $4419.4 \pm 609.6$ abc & $7.9 \pm 1.7$ cdeefghii \\
\hline $1,3,4$ & Konacık, Baskil - Elazığ & $99.6 \pm 1.91 \mathrm{mn}$ & $18.9 \pm 2.3^{\text {lijk }}$ & $13.6 \pm 0.5 \mathrm{abc}$ & $8636.4 \pm 1805.4^{\mathrm{hl}}$ & $5.8 \pm 1.8$ abcdefg \\
\hline $1,2,3,4,5$ & Hacımehmetli, Baskil - Elazığ & $103.2 \pm 5.6^{\mathrm{mn}}$ & $15.2 \pm 0.7$ cdef & $13.3 \pm 1.2 \mathrm{ab}$ & $6087.0 \pm 466.3$ bcdef & $9.9 \pm 0.7^{\text {hij }}$ \\
\hline $1,2,3,4,5$ & Çiğdemlik, Baskil - Elazı̆̆ & $102.7 \pm 2.9 \mathrm{lmn}$ & $17.2 \pm 1.8$ efghiij & $12.5 \pm 0.6^{a b}$ & $4705.4 \pm 819.9$ abcd & $7.3 \pm 0.5^{\text {bcdefghii }}$ \\
\hline $1,3,4,5$ & $\begin{array}{c}\text { Karakaş, İpşir hamlet, Baskil - } \\
\text { Elazığ }\end{array}$ & $117.5 \pm 9.1$ ов̈ & $24.2 \pm 1.2^{n}$ & $25.9 \pm 2.9$ ghiij & $8941.6 \pm 602.1^{\prime}$ & $4.8 \pm 0.4 \mathrm{abcd}$ \\
\hline 1,4 & Kızıluşağı, Baskil - Elazığ & $111.1 \pm 4.9$ nоö & $24.3 \pm 0.9^{n}$ & $29.0 \pm 3.9^{i j}$ & $3977.8 \pm 243.8$ ab & $6.5 \pm 0.4$ abcdefgh \\
\hline 1,4 & Yalındam, Baskil - Elazığ & $95.6 \pm 3.1^{1 \mathrm{~m}}$ & $17.7 \pm 1.0^{\text {fghiijk }}$ & $13.6 \pm 1.5$ ab & $5496.2 \pm 960.5^{\mathrm{abcd}}$ & $9.6 \pm 3.3^{\text {hil }}$ \\
\hline 1,4 & Situşağı, Baskil - Elazığ & $92.2 \pm 1.9^{\mathrm{kl}}$ & $16.6 \pm 1.8^{\text {defghı }}$ & $11.9 \pm 1.6^{\mathrm{a}}$ & $8421.6 \pm 1093.2^{\text {ghı }}$ & $10.4 \pm 1.9^{\mathrm{ij}}$ \\
\hline $1,3,4,5$ & Söğütdere, Baskil - Elazığ & $106.6 \pm 6.0 \mathrm{mno}$ & $24.2 \pm 1.2 \mathrm{mn}$ & $26.7 \pm 3.2^{\text {hiij }}$ & $5430.6 \pm 964.9$ abcd & $6.9 \pm 2.1$ abcdefghı \\
\hline $1,3,4,5$ & İmikuşağı, Baskil - Elazı̆̆ & $97.4 \pm 2.1^{1 \mathrm{~m}}$ & $20.1 \pm 1.4^{\mathrm{kl}}$ & $27.3 \pm 2.0^{\mathrm{iij}}$ & $8051.6 \pm 1972.1^{\text {fghl }}$ & $8.0 \pm 2.9$ defghii \\
\hline $1,3,4,5$ & Tabanbükü, Baskil - Elazığ & $98.9 \pm 5.6^{1 m n}$ & $20.2 \pm 0.7^{\mathrm{kl}}$ & $29.7 \pm 7.0^{j k}$ & $4586.2 \pm 1901.6^{\mathrm{abcd}}$ & $7.4 \pm 2.8^{\text {bcdefghii }}$ \\
\hline $1,3,4,5$ & Altınuşağı, Baskil - Elazığ & $303.9 \pm 2.9^{p}$ & $17.9 \pm 0.6^{\text {hijk }}$ & $20.9 \pm 1.7$ defg & $8758.6 \pm 1114.4^{\mathrm{hl}}$ & $4.7 \pm 0.6^{\mathrm{abcd}}$ \\
\hline $1,2,3,4,5$ & Bilaluşağı, Baskil - Elazığ & $302.2 \pm 5.3^{p}$ & $17.6 \pm 0.8^{\text {fghijk }}$ & $20.6 \pm 1.4^{\text {defg }}$ & $4252.4 \pm 148.2 \mathrm{abc}$ & $6.9 \pm 0.3$ abcdefghı \\
\hline 1,4 & Suyatağı, Baskil - Elazı̆̆ & $107.4 \pm 8.4 \mathrm{mno}$ & $16.5 \pm 0.3^{\text {defghı }}$ & $20.4 \pm 1.3^{\text {def }}$ & $6428.8 \pm 258.3^{\text {cdefg }}$ & $10.6 \pm 0.5^{\mathrm{ij}}$ \\
\hline 1,4 & Höyükköy, Baskil - Elazığ & $76.1 \pm 3.2^{i}$ & $16.9 \pm 0.5^{\text {defghiij }}$ & $19.0 \pm 0.8^{\text {cde }}$ & $5744.2 \pm 756.6$ abcde & $4.1 \pm 2.2^{\mathrm{ab}}$ \\
\hline 1,4 & Kumlutarla, Baskil - Elazığ & $81.0 \pm 5.1^{\mathrm{jk}}$ & $16.7 \pm 1.6^{\text {defghii }}$ & $20.7 \pm 2.4^{\text {defg }}$ & $4549.4 \pm 384.3^{\mathrm{abcd}}$ & $7.4 \pm 0.6^{\text {bcdefghii }}$ \\
\hline
\end{tabular}

Each value is expressed as mean \pm SD of five replicates.

Values with different small letters in the same column are significantly different at the level of 0.05 ( $P<0.05)$.

Truffle types (1: T. boudieri , 2: T. claveryi, 3: T. olbiensis, 4: P. lefebvrei, 5: P. juniperi) and locality (Malatya-Elazı̆ provincial border zone and its vicinity) from Akyüz et al. [13]. 
The physical and chemical properties of the soil samples from the locations where different truffle species grow are shown in Table 2. Our analyses have shown that the soil has alkaline characteristics and it has lime content. It was observed that the level of organic material and nitrogen was low, so was the level of electirical conductivity. Based on these and other observations, it was understood that truffles prefer to grow in sandy soil that has high amounts of phosphorus, potassium and sodium (Table 2). Previous research have shown that the amount of $\mathrm{N}, \mathrm{P}$, and $\mathrm{K}$ that exist in the soil can affect the mycorrhizal structure between the truffle and the host plant $[8,22,25,34-36]$. It was also indicated that many truffle types grow in soil with sandy properties [34,37], but the physical and chemical characteristics of these soils can change based on where the truffle grows, and the biotic and abiotic factors. Researchers have indicated that areas with sandy-clayey or sandy soil, which are rich in terms of organic material, and basins, valleys and plain fields through which riverbeds cross, are most suitable for truffle growth [7]. Low pH is known to cause a reduction in the calcium content of the soil and tehrefore affects the truffles in the wild in a negative way. Organic matter provides the essential nutrients and energy for macrofungi, improving the physical properties of the soil and giving it a spongy structure by linking separate particles in it $[11,38]$.

It has been indicated in earlies studies that the physical and chemical characteristics of the soil can affect the growth of different types (Terfezia, Tirmania, Picoa species) of truffles. It was also mentioned that depending on the type of soil (sandy, clay, silty, loam calcerous etc.), the humidity level (2-6\%), $\mathrm{pH}$ (5.8-8.5) level, amount of $\mathrm{CaCO}_{3}(4-58 \%)$, and the amount of organic material (0.44-2.59\%) should be at a certain level, and the soils should have a low level of salinity, organic carbon, electrical conductivity and $\mathrm{C} / \mathrm{N}$. On the other hand, this can be different for certain truffle species (Terfezia spp.) which prefer different soil types (acidic and sandy) and $\mathrm{pH}$ level $[8,11,26,30,32-34,37,39-43]$. All our studies comply with the observations and results of the research mentioned above, and it is especially important that the physical and chemical characteristics of the soils that the truffle types grow can vary (Table 2).
In conclusion, truffle development is closely related to soil characteristics, climatic conditions, and particularly precipitation, which mainly occurs in early spring seasons. Early spring precipitation represents a significant potential for the growth of truffles. Indeed, as stated in the aforementioned studies, the physical and chemical properties of the soil including the $\mathrm{pH}$ level, texture, saturation, amount of organic material and lime, clearly affect the growth of truffle types in the concerned region.

\section{ACKNOWLEDGEMENTS}

We are grateful to the Scientific and Technical Research Council of Turkey for supporting this project (TÜBITAK3001-1140065).

\section{References}

1. Ü. Avcl, Tehtitler ve biyolojik çeşitlilik, Ekoloji Magazin, 7 (2005) 12-16.

2. A. Kence, Türkiye'nin biyolojik zenginlikleri, T.Ç.S.V., (1987) 316.

3. M. Kışlalıoğlu, F. Berkes, Biyolojik çeşitlilik, T.Ç.S.V., (1987) 122.

4. Y. Coşkun, Biyoçeşitlilik, Türkiye sorunlarına çözüm konferansı, Diyarbakır, (2001) 24. http://www.dicle. edu.tr/a/yukselc/meropshtml/dokuman/TSCK.htm. (Accessed 05.02.2015).

5. G. Moreno, P. Alvarado, J.L. Manjón, Hypogeous desert fungi, In: V. Kagan-Zur, N. Roth-Bejerano, Y. Sitrit, A. Morte (eds), Desert truffles, Springer Berlin Heidelberg, (2014) 3-20.

6. J. Diez, J.L. Manjon, F. Martin, Molecular phylogeny of the mycorrhizal desert truffles (Terfezia and Tirmania), host specificity and edaphic tolerance, Mycologia, 94 (2002) 247-259.

7. Q.A. Mandeel, A.A. Al-Laith, Ethnomycological aspects of the desert truffle among native Bahraini

8. and non-Bahraini people of the Kingdom of Bahrain, J. Ethnopharmacol., 110 (2007) 118-129.

9. V. Kagan-Zur, N. Roth-Bejerano, Desert truffles, Fungi, 1 (2008) 32-37.

10. J.M. Trappe, A.W. Claridge, D. Arora, W.A. Smit, Desert truffles of the African Kalahari: ecology, ethnomycology and taxonomy, Econ. Bot., 62 (2008) 521-529.

11. V. Kagan-Zur, N. Roth-Bejerano, Y. Sitrit, A. Morte, Desert truffles: phylogeny, physiology, distribution and domestication, Springer-Verlag Berlin Heidelberg, 2014.

12. K. Gezer, O. Kaygusuz, A. Çelik, M. Işıloğlu, Ecological characteristics of truffles growing in Denizli province, Turkey, J. Food. Agric. Environ., 12 (2014) 1105-1109.

13. A. Türkoğlu, M.A. Castellano, New records of some Ascomycete truffle fungi from Turkey, Turk. J. Bot., 38 (2014) 406-416. 


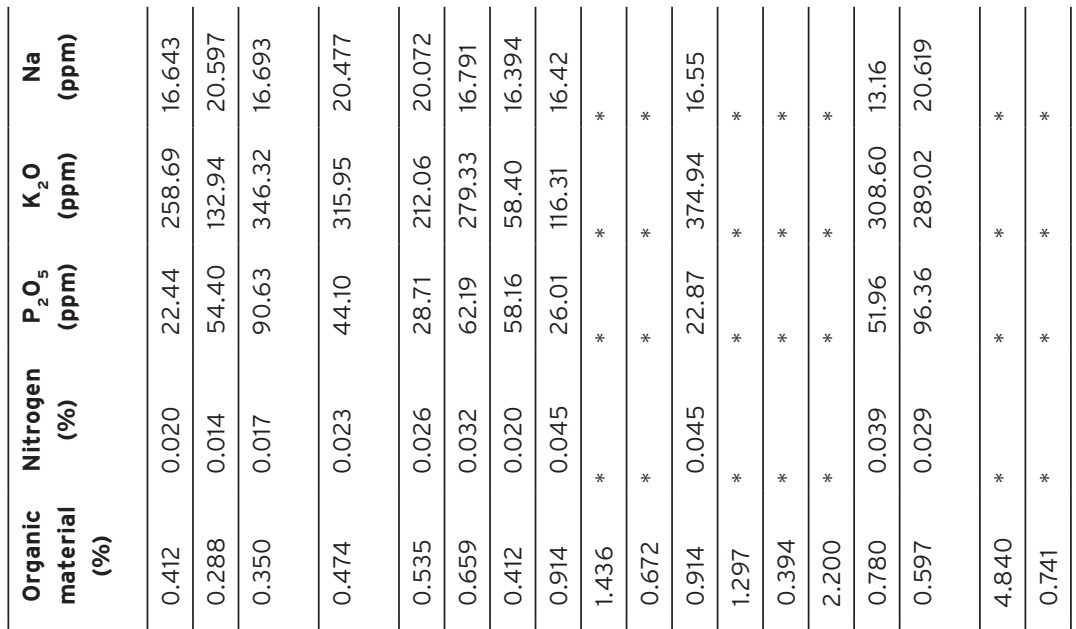

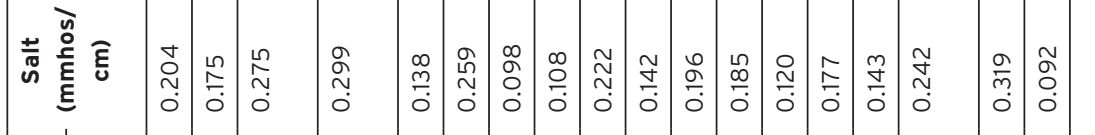

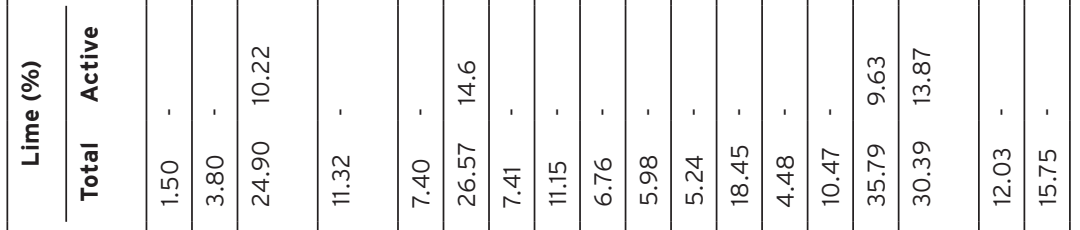

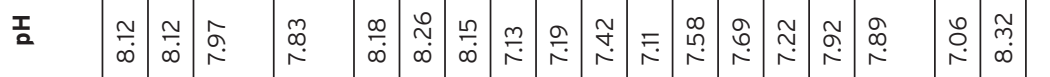
核 
14. M. Akyüz, S. Kırbağ, B. Bircan, Y. Gürhan, Diversity and distribution of arid-semi arid truffle (Terfezia and Picoa) in Elazığ-Malatya region of Turkey, Mycosphere, 6 (2015) 766-783.

15. G. Bouyoucos, Hydrometer method improved for making particle size analysis of soils, Agron. J., 54 (1963) 464-465.

16. L.E. Allison, C.E. Moodie, Carbonate, C.A. Black et al., (eds), Methods of soil analysis, Part II, Agronomy series. Am. Soc. Agron., USA, (1965) 1379-1400.

17. A. Walkely, L.A. Black, An examination of the determining method for determining organic soil matter and an proposed modifi cation of the chromic acid titration method, Soil. Sci., 37 (1934) 29-38.

18. D.W. Nelson, L.E. Sommers, Total carbon, organic carbon and organic matter, In: A.L. Page et al. (eds), Methods of soil analysis. Am. Soc. Agron., Madison WI USA, (1996) 961-1010.

19. J.M. Bremner, Methods of soil analysis, In: C.A. Black (editor), Chemical and microbiological properties, Am. Soc. Agron., USA, 1965.

20. M.L. Jackson, Soil chemical analysis, Englewood Cliffs, NJ, Prentice Hall Inc., USA, 1958.

21. J. Murphy, J.P. Riley, A modified single solution method for the determination of phosphorus in natural water, Anal. Chim. Acta., 27 (1972) 31-36.

22. M. Akyüz, S. Kırbağ, B.Bircan B, Medical characteristics of arid-semi arid truffle (Terfezia and Picoa) in the Elazığ-Malatya region of Turkey. Hacettepe J. Biol. Chem., 43 (2015) 301-308.

23. A. Gutiérrez, A. Morte, M. Honrubia, Morphological characterization of the mycorrhiza formed by Helianthemum almeriense Pau with Terfezia claveryi Chatin and Picoa lefebvrei (Pat.) Maire, Mycorrhiza, 13 (2003) 299-307.

24. Y. Ferdman, S. Aviram, N. Roth-Bejerano, J.M. Trappe, V. Kagan-Zur, Phylogenetic studies of Terfezia pfeilii and Choiromyces echinulatus (Pezizales) support new genera for Southern African truffles: Kalaharituber and Eremiomyces, Mycol. Res., 109 (2005) 237-245.

25. M. Loizides, C. Hobart, G. Konstandinides, Y. Yiangou, Desert truffles: The mysterious jewels of antiquity, Field Mycol., 13 (2012) 17-21.

26. A. Slama, M. Gorai, Z. Fortas, A. Boudabous, M. Neffati, Growth, root colonization and nutrient status of Helianthemum sessiliflorum Desf. inoculated with a desert truffle Terfezia boudieri Chatin, Saudi J. Biol. Sci., 19 (2012) 25-29.

27. S. Jamali, Z. Banihashemi, Hosts and distribution of desert truffles in Iran, based on morphological and molecular criteria, J. Agric. Sci. Technol., 14 (2012) 1379-1396.

28. N. Roth-Bejerano, A. Navarro-Ródenas, A. Gutiérrez, Types of mycorrhizal association, In: V. Kagan-Zur, N. Roth-Bejerano, Y. Sitrit, A. Morte (eds), Desert truffles, Springer Berlin Heidelberg, (2014) 69-80.

29. A. Zambonelli, D. Donnini, G.L. Rana, S. Fascetti, G.M.N. Benucci, M. Lotti, A. Mortee, L. Khabarf, A Bawadekjig, F. Piattonia, R. Compagnoh, G. Venturella Hypogeous fungi in Mediterranean maquis, arid and semi-arid forests, Plant Biosystems, 148 (2014) 392 401.
30. V. Kagan-Zur, M. Akyuz, Asian Mediterranean desert truffles, In: V. Kagan-Zur, N. Roth-Bejerano, Y. Sitrit, A. Morte (eds), Desert truffles, Springer Berlin Heidelberg, (2014) 159-171.

31. A. Morte, M. Zamora, A. Gutiérrez, M. Honrubia, Desert truffle cultivation in semiarid Mediterranean areas, In: A. Concepción, J.M. Barea, S. Gianinazzi, G. Vivienne (eds.), Mycorrhizas-functional processes and ecological impact, Springer Berlin Heidelberg, (2009) 221-233.

32. E. Bonifacio, A. Morte, Soil Properties. In: V. KaganZur, N. Roth-Bejerano, Y. Sitrit, A. Morte (eds), Desert truffles, Springer Berlin Heidelberg, (2014) 57-67.

33. L. Bradai, S. Bissati, H. Chenchouni, Desert truffles of the north Algerian Sahara: diversity and bioecology, Emir. J. Food. Agric., 26 (2014) 429-439.

34. L. Bradai, S. Bissati, H. Chenchouni, K. Amrani, Effects of climate on the productivity of desert truffles beneath hyper-arid conditions, Inter. J. Biometeorol. 59 (2015) 907-915.

35. Z. Fortas, G. Chevalier, Effet des conditions de culture sur la mycorhization de I'Helianthemum guttatum par trois especes de terfez des genres Terfezia et Tirmania d'Algerie, Can. J. Bot., 70 (1992) 2453-2460.

36. V. Kagan-Zur, E. Raveh, S. Lischinsky, N. RothBejerano, Initial association between Helianthemum and Terfezia is enhanced by low iron in growth medium, New Phytologist, 127 (1994) 567-570.

37. M. Zaretsky, V. Kagan-Zur, D. Mills, N. Roth-Bejerano, Analysis of mycorrhizal associations formed by Cistus incanus transformed root clones with Terfezia boudieri isolates, Plant. Cell. Rep., 25 (2006) 62-70.

38. G. Giovannetti, N. Roth-Bejerano, E. Zanini, V. KaganZur, Truffles and their cultivation, Hortic. Rev., 17 (1994) 71-107.

39. K. Haktanır, S. Arcak, Soil Biology, Ankara University Agricultural Falcuty Periodicals, Ankara University Press, Ankara. 1997.

40. G. Moreno, R. Galan, A. Ortega, Hypogeous fungi from continental Spain, Cryp. Mycol., 7 (1986) 201-229.

41. F.W. Taylor, D.M. Thamage, N. Baker, N. Roth-Bejerano, V. Kagan-Zur, Notes on the Kalahari desert truffle, Terfezia pfeili, Mycol. Res., 99 (1995) 874-878.

42. A.R. Hashem, A.M. Al-Obaid, Mineral composition of soil and wild desert truffies in Saudi Arabia, J. King. Saud. Univ., 8 (1986) 5-10.

43. G.M. Kovacs, C. Vagvolgyi, F. Oberwinkler, In vitro interaction of the truffle Terfezia terfezioides with Robinia pseudoacacia and Helianthemum ovatum, Folia Microbiol., 48 (2003) 360-378.

44. I. Sbissi, F. Ghodhbane-Gtari, M. Neffati, H. Ouzari, A. Boudabous, M. Gtari, Diversity of the desert truffle Terfezia boudieri Chatin in southern Tunisia, Can. J. Microbiol., 57 (2011) 599-605. 